The Review of Finance and Banking

Volume 13, Issue 2, Year 2021

http://dx.doi.org/10.24818/rfb.21.13.02.02, Pages 109-120

S print ISSN 2067-2713, online ISSN 2067-3825

\title{
THE DETERMINANTS OF FINANCIAL INCLUSION AND DIGITAL FINANCIAL INCLUSION IN INDIA: A COMPARATIVE STUDY
}

\author{
SRINIVASU BATHULA AND ANKITA GUPTA
}

\begin{abstract}
The access to the financial services and digital financial services in India has not yet transformed into their frequent use. Therefore, the present paper provides a comparative analysis of the individual level determinants for few main indicators of the two main dimensions of financial inclusion and digital financial inclusion: access and use, based on binary probit regression analysis using World Bank's 2017 Global Findex data. The paper concludes that education and workforce participation are positively associated with the access to financial services and digital financial services and also with the use of most of the financial services and digital financial services. Another interesting result is that being a woman and poor reduces the probability of using mobile banking but do not affect traditional banking.
\end{abstract}

\section{INTRODUCTION}

Financial Development leads to economic development of an economy. Financial development follows either a supply led or demand following route to create enabling conditions for the economic growth. Economic growth is accelerated through financial deepening via enhanced access of finance to those who do not have it themselves. Although financial deepening has showed signs of improvement, the scope and visibility of structured finance has not increased to the same extent (Mohan 2006). Therefore, financial inclusion has been an important policy agenda of Indian policy makers, mainly after 2005. Though financial inclusion is not specifically mentioned in United Nation's list of 17 Sustainable Development Goals (SDGs), greater access to financial services is a key enabler for many of them (Klapper, El-zoghbi, and Hess 2016). Financial inclusion is regarded critical for inclusive development that leads to long-term growth (Thorat 2007). The Rangarajan Committee on Financial inclusion has defined financial inclusion as 'the process of ensuring access to financial services and timely and adequate credit where needed by vulnerable groups such as weaker sections and low income groups at an affordable cost' (RBI 2008, p. 297). With the Introduction of Digital India initiative in India, digital financial inclusion has gained attention in the recent times. Digital financial inclusion has been defined by Consultative Group to Assist Poor (CGAP), a World Bank group as 'digital access to and use of formal financial services by excluded and underserved populations. Such services should be suited to the customers' needs and delivered responsibly, at a cost both affordable to customers and sustainable for providers' (Layman and Lauer 2015, 1). The main difference between digital financial inclusion and financial inclusion is that digital financial inclusion employs the use of cost saving digital technologies such as mobile phones,

Received by the editors April 22, 2021. Accepted by the editors October 21, 2021.

Keywords: Financial Inclusions, Digital Financial Inclusion, Financial Services, Digital Financial Services, Mobile Banking.

JEL Classification: G00, G20, G21, 016.

Srinivasu Bathula, PhD, Associate Professor, Department of Economics, Jamia Millia Islamia, Mohammad Ali Jauhar Marg, New Delhi, India-110025. E-mail: bsrinivas07@gmail.com.

Ankita Gupta* (Corresponding Author), Research Scholar, Department of Economics, Jamia Millia Islamia, Mohammad Ali Jauhar Marg, New Delhi, India-110025. E-mail: guptaankita184@gmail.com.

This paper is in final form and no version of it will be submitted for publication elsewhere. 
laptop, debit cards, credit cards to access and use the financial services provided by formal financial institutions whereas under financial inclusion, financial services can be accessed and use by visiting the brick-and-mortar bank branches only. Thus, digital financial inclusion aims to advance financial inclusion by providing access to financial services in a more convenient way to the previously unserved and underserved population. However, the access to financial services has not transformed into their usage since globally, 460 million adults have a dormant account, and 380 million a low-use account (Demirguc-Kunt et al. 2015). The Indian policymakers in National Strategy for financial inclusion, 2019-24, have therefore focused on not just access to financial services but also usage of those services for the consumers to get benefitted.

Digital finance can aid in the reduction of poverty and hunger, the advancement of gender equality, educational and health-care opportunities. (Manyika et al. 2016). Digital financial services also help in achieving UN Sustainable Development Goals 1 to 5, and Goal 8, i.e., in ending poverty, hunger, ensuring healthy lives, availability and equal access to quality education, gender equality and economic growth (Suzman 2016). Thus, the importance of financial inclusion and digital financial inclusion has been widely recognised. Over the years, the focus has been shifted from the access to the usage of financial and digital financial services. The access and use of digital financial services remain limited even among people who use financial services. Various empirical studies such as Allen et al. (2016), Zins \& Weil (2016), Königsheim et al. (2017), Ouma et al. (2017) have identified the individual level determinants and national level determinants for financial inclusion, use of digital financial services, saving behaviour, barriers to financial inclusion and other banking determinants. There is a need to identify the determinants of digital financial inclusion in India and compare them with the determinants of financial inclusion so as to enable digital transformation of financial services amongst individuals and to deal with financial exclusion and digital financial exclusion. Thus, it is important to identify which individual level characteristics determine the access and use of financial services as well as digital financial services. The analysis in the present paper is different from the previous studies in following aspects: i) individual level determinants of digital financial inclusion have not been identified in India ii) the determinants of the financial inclusion have not been compared with the determinants of digital financial inclusion earlier. iii) determinants of the indicators for the access to financial services and digital financial services have not been differentiated from the determinants of the indicators for the use of financial services and digital financial services respectively. iv) the determinants of the access to financial services have not been compared with the determinants of access to digital financial services. v) the determinants of the use of financial services have not been compared with the determinants of the use of digital financial services. The paper contributes to the available literature by looking at all these aspects and understanding what individual level characteristics determines the financial inclusion and digital financial inclusion in India.

The rest of the paper is structured as follows: Section 2 reviews the related literature. Section 3 delineates the data structure and the variables used and Section 4 presents the research methodology. Further, Section 5 discuss the results and findings. Section 6 concludes the paper and provides some important policy implications.

\section{Literature Review}

This section provides an overview of the literature associated the determinants of financial inclusion and digital financial inclusion. Various studies have identified the individual level determinants and also country level determinants of financial inclusion and digital financial inclusion.

Allen et al. (2016) used 2011 Global Findex data to explain individual level characteristics explaining variation in ownership and use of formal accounts. He observed that richer, older, urban, educated, employed, and married individuals have a higher probability of owning an account. Older, richer, educated or married individuals have high probability of using an account. Zins \& Weill (2016) studied determinants of financial inclusion in Africa using Global Findex 
data 2014. It was observed that a man, richer, more educated and older are the significant determinants financial inclusion. Financial inclusion is more influenced by Education and income. The major determinant of barrier to financial inclusion was found to be education with the negative association. The paper concluded that mobile banking can be treated as a substitute for traditional banking as both have the same determinants. Fungáčová \& Weill (2014) evaluated financial inclusion in China using Global findex data 2011 and found higher income, better education, being a man, and being older to be associated with greater use of formal accounts and formal credit in China. Income and education influence the use of alternative sources of borrowing in China.

Allen et al. (2016) showed that likelihood of opening an account among countries is negatively associated with high cost of opening and using bank accounts and positively associated with the higher the level of branch or ATM penetration, and the higher the level of the legal rights index and of the political stability rating. The higher use of bank accounts was found to be positively associated with government transfer payments made through bank and saving schemes and tax incentive programs to promote savings. Evans (2018) identified positive association between internet, mobile phones and financial inclusion. Macro-level indicators such as capital formation, primary enrollment, bank credit, broad money, population growth, remittance and agricultural value added were also found to be positively associated with financial inclusion. Shen et al. (2018) findings show that the goal of financial inclusion can be achieved by improving the financial literacy of residents and popularizing the Internet usage by promoting the use of digital financial products. Ouma et al. (2017) showed that the probability to save using mobile financial services is higher for woman than men whereas amount saved by man is more than that of women. The amount saved was found to be higher for men than women because men have a better paying career comparatively. Also, married people, educated are also likely to save more while family size is found to be negatively related to the likelihood of savings. Few studies have also estimated indicators for future adoption and use of digital financial services. Trinugroho et al. (2017) found the determinants of readiness to adopt digital financial services. The socio-economic factors which influence financial literacy such as education and age are found to be important factors, age being negatively associated implying young people are more ready to adopt digital financial services. High income is also an important determinant of the readiness. Information and communication technology infrastructure also explained the perceived readiness to adopt digital financial services. Königsheim et al. (2017) brings out that financial knowledge and risk tolerance positively influence the probability of using the digital financial services. The likelihood of using digital financial service increases with the respondent being male and having university degree. Age was found to be negatively and significantly correlated with using digital financial services.

High level of financial inclusion contributes significantly to the stability in the banking sector, resulting in increased bank resilience (Vo et al., 2021; Ahamed \& Mallick, 2019). Banks that have a larger consumer deposit funding share and lower marginal costs of offering financial services, as well as those that work in countries of higher institutional efficiency, have a better positive relationship. Banna \& Alam (2021) brings out that high level of digital financial inclusion also positively contributes to bank stability. Khera et al. (2021a) brings out that digital financial inclusion contributes to economic growth and is driven by access to infrastructure, financial literacy, digital literacy, and quality of institutions. Geng and He (2021) identified that digital financial inclusion leads to sustainable employment with significant impact in upper-middle-income countries and high-income countries and insignificant impact in lower-middle-income economies.

Ozili (2018) found a two-way causality between digital finance and finance inclusion. Even though digital finance has many benefits associated with it such as convenience and instant services, it benefits the urban areas drives sustainable employment with significant impact in more who have high incomes. Fernandes, Borges, and Caiado (2021) used Autoregressive Distributed Lag (ARDL) model to conclude that digital financial services such as financial transactions 
via ATMS, Point-of-Sales, mobile banking and electric money contributes to financial inclusion in Mozambique. Ozili (2020) argued that digital finance is pro-poor and can exacerbate the already existing inequalities thus leading to greater financial exclusion. There is a need to de-risk digital finance at operational stage to shield the poor from digital risk. Wang et al. (2020) provided a quantitative analysis to show that while digital finance has increased financial sector productivity marginally in China, there are major gaps in the effect of provincial efficiency. Backward regions, however, do not benefit much from the digital finance as they are the latecomers and hence may face disadvantages as a result. Khera et al. (2021b) constructed an aggregated index combining parameters of digital financial inclusion and financial inclusion. The key findings were that adoption of fintech has driven financial inclusion and the performance of countries varies widely with higher performance in Africa, Asia and the Pacific regions. Sahay et al. (2020) also constructed a financial index for 52 countries combining the components of both financial inclusion and digital financial inclusion. Digital financial inclusion increased between 2014 and 2017 even when traditional financial inclusion was stalling or decelerating. It has been identified that digital financial inclusion can address the gender gaps in financial inclusion. However, expansion of digital financial inclusion can also create new forms of exclusion as many people do not own mobile phones, computes or internet.

On the basis of the review of above-mentioned literature, it is evident that there is not sufficient literature available related to the individual level determinants of digital financial inclusion, particularly in India. Further, no study has differentiated the determinants for the two main dimensions, i.e., access and use, of financial inclusion and digital financial inclusion. The differentiation between the determinants is important as access and use are two main dimensions of financial inclusion and digital financial inclusion. The present paper contributes to the literature in two ways. First, by differentiating between the individual level determinants of the access to digital financial services and the use of digital financial services in India. Second, by comparing the individual level determinants for the access and use of digital financial inclusion with that of financial inclusion in India. The individual level determinants of the access and use of financial services as well as digital financial services will help the policy makers in formulating specific policies to deal with financial exclusion and digital financial exclusion at an individual level.

\section{DATA}

The paper is based on the secondary data. World Bank's 2017 Global Findex micro data has been used for the analysis ${ }^{1}$. The paper focuses on few main indicators of financial inclusion and digital financial inclusion. The importance of the use of financial services and digital financial services along with the access has been recognized lately. Therefore, the paper focuses on both the dimensions of financial inclusion and digital financial inclusion, i.e., access and use of financial services as well as access and use of digital financial services. Access to financial services is measured through ownership of formal account and the use of financial services is measured through formal saving and formal credit. Formal account is defined as individual having an account either at a financial account or through a mobile money provider. Formal saving means that the individual has saved using a financial institution account in the past 12 months. Formal credit is defined as borrowing from a financial institution in the past 12 months by an individual.

'Digital financial services (DFS) are financial services which rely on digital technologies for their delivery and use by consumers' (Pazarbasioglu et al. 2020). Therefore, the access for digital financial inclusion is measured by having access to a debit card, credit card and owning a mobile phone while the use is measured by the use of debit card and credit card in past 12 months, and bills payments made online over the internet.

\footnotetext{
${ }^{1}$ Individual level data are available at: http://www.worldbank.org/globalfindex.
} 
Further, mobile banking is also analyzed using mobile account variable which refers to the fact that an individual has a mobile money account. Traditional banking is defined as an individual having an account at a financial institution and not through mobile phone.

All of the above variables are incorporated as dummy variables in the paper. The value of dummy would be equal to one if an individual responded "yes" and "zero" otherwise. Table 1 illustrates the descriptive statistics of all the dependent variables used in the study.

\begin{tabular}{|c|c|c|c|c|}
\hline \multicolumn{5}{|c|}{ Table I: Descriptive Statistics of the Dependent Variables Used in the Study } \\
\hline S.No. & Variable & Frequency (\%) & Mean & Standard Deviation \\
\hline 1. & Formal Account & $2380(79.3)$ & .793 & .405 \\
\hline 2. & Owns a Mobile Phone & $2063(68.8)$ & .688 & .463 \\
\hline 3. & Owns a Debit Card & $943(31.4)$ & .314 & .464 \\
\hline 4. & Used Debit Card & $330(11)$ & .11 & .313 \\
\hline 5. & Owns a Credit Card & $88(2.9)$ & .029 & .169 \\
\hline 6. & Used Credit Card & $65(2.2)$ & .022 & .146 \\
\hline 7. & Formal Savings & $570(19)$ & .19 & .392 \\
\hline 8. & Formal Borrowings & $197(6.6)$ & .066 & .248 \\
\hline 9. & Paid Bills Over the Internet & $81(2.7)$ & .027 & .162 \\
\hline 10. & Account at Financial Institution & $2379(79.3)$ & .793 & .405 \\
\hline 11. & Mobile Money Account & $65(2.2)$ & .022 & .146 \\
\hline
\end{tabular}

\section{Methodology}

The analysis in the paper is performed using binary probit regression to evaluate and compare the determinants of financial inclusion and digital financial inclusion. The paper initially compares the determinants of access to financial services and access to digital financial services indicators and then compare the determinants of use of financial services and use of digital financial services indicators. Further, the paper also compares the determinants of traditional banking and money banking. The equation of the model is:

$$
X_{i}=\alpha+\beta \text { Age }_{i}+\gamma \text { Gender }_{i}+\zeta \text { Workforce }_{i}+\text { SIncome }_{i}+\rho \text { Education }_{i}+\varepsilon_{i}
$$

$\mathrm{X}$ is the dependent variable which is financial inclusion and digital financial inclusion indicators and i refers to a particular individual. The explanatory variables included in the model are age, gender, workforce participation, income and education.

\begin{tabular}{|c|c|c|c|c|}
\hline \multicolumn{5}{|c|}{ Table II. Descriptive Statistics of the Independent Variables Used } \\
\hline S.No. & Variable & Observations & Mean & Standard Deviation \\
\hline 1. & Age & 3,000 & 37.43 & 15.436 \\
\hline 2 & Female & 3,000 & .516 & .499 \\
\hline 3. & In Workforce & 3,000 & .562 & .496 \\
\hline 4. & Out of Workforce & 3,000 & .438 & .496 \\
\hline 5. & Poorest 20 per cent & 3,000 & .182 & .386 \\
\hline 6. & Second 20 per cent & 3,000 & .198 & .398 \\
\hline 7. & Third 20 per cent & 3,000 & .201 & .401 \\
\hline 8. & Fourth 20 per cent & 3,000 & .199 & .399 \\
\hline 9. & Richest 20 per cent & 3,000 & .22 & .414 \\
\hline 10. & Primary Education or Less & 3,000 & .656 & .475 \\
\hline 11. & Secondary Education & 3,000 & .279 & .448 \\
\hline 12. & Tertiary Education or More & 3,000 & .062 & .241 \\
\hline
\end{tabular}

The paper uses two measures to represent age, similar to Zins and Weill (2016); Allen et al. (2016): the exact age of the respondent and age squared i.e., square of the respondent age. The second measure of the age deals with the non-linear relation between age and the dependent variable. Gender is a dummy variable equal to one if respondent is female and zero 
otherwise. Workforce is another dummy variable with dummy equal to one if respondent is in workforce and zero if out of workforce. Income has been divided into five income quintiles in Global Findex data which are poorest 20 per cent, second 20 per cent, third (or middle) 20 per cent, fourth 20 per cent and richest 20 per cent. The richest 20 per cent is the omitted dummy variable in the model. Education involves three dummy variables which are completed primary education or less, completed secondary education and completed tertiary education or more where the first dummy is the omitted one. Table II reports the descriptive statistics of the independent variables used in the study.

\section{Results and Discussions}

This section provides the results for the determinants of financial inclusion and digital financial inclusion based on binary probit regression analysis. The results for access and use are analyzed separately in different sub-sections. Thereafter, the determinants of mobile banking and traditional banking are analyzed.

5.1. Determinants of the access to financial services and digital financial services. Table III shows the determinants for the indicators of access to financial services and access to digital financial services. The dependent variable for access to financial services is Formal Account while dependent variable for access to digital financial services is owning a mobile phone, access to debit card and access to credit card.

It has been observed that age, age squared, workforce participation and education are significant determinants of having access to a formal account. While the probability of having access to a formal account increases with age, it decreases after a specific age has been attained which is evident from the positive coefficient for age and negative coefficient for age squared. Workforce participation and higher education level increases the probability of having access to formal account. Secondary education increases the probability of having formal account by 10.92 per cent and tertiary education increases the probability by 18.68 per cent. Only Fourth income quintile is significant determinant of having access to formal account. Gender is not significantly associated with the access to formal account which implies that gender does not explain the low access to financial services in India. This result is different from the findings by Fungáčová \& Weill (2014) and (Zins and Weill 2016) in China and Africa respectively where gender explains the low level of access to financial services.

On the other hand, income, education and workforce participation is a significant determinant for all the indicators of access to digital financial services. Higher income, education and workforce participation increases the probability of having access to digital financial services. The results support the argument by Ozili (2020) that digital finance is pro-poor and the impact of digital financial services on improving welfare depends on the socio-economic status of the people, disproportionately benefitting richer and educated ones more. Then, being a woman decreases the probability of owning a mobile phone by 13.16 per cent and debit card by 9.19 per cent. Age is non-linearly associated with owning a mobile phone and debit card.

The main findings of the analysis are that being a poor significantly reduces the probability of having access to digital financial services. This relationship is not significant for access to financial services. Being a woman does not affect the probability of having access to formal account but significantly reduces the probability of digital access to financial services, i.e., owning a mobile phone and debit card. This exhibits women still face barriers in accessing digital financial services whereas such barriers have been greatly resolved in terms of access to financial services in India due to schemes such as Pradhan Mantri Jan Dhan Yojana (PMJDY) ${ }^{2}$. On the other hand, education, age and workforce participation have the same relation with both

\footnotetext{
${ }^{2}$ PMJDY allow an unbanked individual to open a Basic Saving Bank Deposit (BSBD) account in any bank branch or Business Correspondent (BC) outlet. Thereby, PMJDY scheme ensures that every individual has access to all the financial services such as savings, remittance, credit, insurance, etc. The scheme is a national mission aimed at Financial Inclusion.
} 
the access to financial services and access to most of the digital financial services with education and workforce participation having positive association and age having non-linear association with all but not owning a credit card.

\begin{tabular}{|c|c|c|c|c|}
\hline \multirow[t]{4}{*}{ Variables } & Access to & \multicolumn{3}{|c|}{ Access to } \\
\hline & Financial Services & \multicolumn{3}{|c|}{ Digital Financial Services } \\
\hline & Formal & Owns a & Owns a & Owns a \\
\hline & Account & mobile phone & debit card & credit card \\
\hline \multirow{2}{*}{ Respondent age } & $.0159^{*}$ & $.0073^{*}$ & $.0224^{*}$ & .0005 \\
\hline & $(-.0022615)$ & $(.0027506)$ & $(.003222)$ & $(.0008382)$ \\
\hline \multirow[t]{2}{*}{ Age squared } & $-.00015^{*}$ & $-.00011^{*}$ & $-.00025^{*}$ & $-5.96 \mathrm{e}-07$ \\
\hline & $(.0000257)$ & $(.0000312)$ & $(.0000377)$ & $(9.26 \mathrm{e}-06)$ \\
\hline \multirow[t]{2}{*}{ Female } & -.0206 & $-.1316^{*}$ & $-.0919^{*}$ & -.0082 \\
\hline & $(.0158683)$ & $(.0183253)$ & $(.0192006)$ & $(.0058705)$ \\
\hline \multirow{2}{*}{ In Workforce } & $.06434^{*}$ & $.0781^{*}$ & $.0679^{*}$ & $.0109^{* *}$ \\
\hline & $(.0163701)$ & $(.0190112)$ & $(.019457)$ & $(.0058508)$ \\
\hline \multirow[t]{2}{*}{ Poorest 20 per cent } & -.0319 & $-.0999^{*}$ & $-.2461^{*}$ & $-.0151^{*}$ \\
\hline & $(.0254023)$ & $(.0305111)$ & $(.0184449)$ & $(.0056868)$ \\
\hline \multirow[t]{2}{*}{ Second 20 per cent } & -.01513 & $-.1230^{*}$ & $-.2077^{*}$ & $-.0159^{*}$ \\
\hline & $(.0242716)$ & $(.0300497)$ & $(.0199171)$ & $(.0056037)$ \\
\hline \multirow[t]{2}{*}{ Third 20 per cent } & -.00608 & $-.1038^{*}$ & $-.1427^{*}$ & $-.0143^{*}$ \\
\hline & $(.0239038)$ & $(.0294376)$ & $(.0217883)$ & $(.0055313)$ \\
\hline \multirow[t]{2}{*}{ Fourth 20 per cent } & $-.0454^{* *}$ & $-.0559^{* *}$ & $-.1002^{*}$ & $-.0186^{*}$ \\
\hline & $(.0251069)$ & $(.0288175)$ & $(.0227562)$ & $(.004973)$ \\
\hline \multirow[t]{2}{*}{ Secondary education } & $.1092^{*}$ & $.0832^{*}$ & $.2907^{*}$ & $.01404^{* *}$ \\
\hline & $(.0154069)$ & $(.0206942)$ & $(.0231827)$ & $(.0080198)$ \\
\hline \multirow{2}{*}{ Tertiary education or more } & $.1868^{*}$ & $.1463^{*}$ & $.5322^{*}$ & $.07301^{* *}$ \\
\hline & $(.0124022)$ & $(.0311076)$ & $(.0338674)$ & $(.0246018)$ \\
\hline Observations & 3,000 & 3,000 & 3,000 & 3,000 \\
\hline Log Likelihood & -1434.9138 & -1747.8552 & -1513.3683 & -368.80131 \\
\hline Likelihood Chi-Square Value & 187.21 & 230.02 & 708.41 & 56.90 \\
\hline \multicolumn{5}{|l|}{ Predicted Probability } \\
\hline Pseudo R2 & 0.0612 & 0.0617 & 0.1897 & 0.0716 \\
\hline \multicolumn{5}{|c|}{ Source: Author's Calculations } \\
\hline \multicolumn{5}{|c|}{ Table displays the marginal effects of the probit estimation and standard errors of the variables are } \\
\hline represented in parenthese & $*^{*}$ and $* *$ denotes signif & ant at 5 percent a & d 10 percent $r$ & tively. \\
\hline
\end{tabular}

5.2. Determinants of the use of financial services and digital financial services. The results of binary Probit regression showing determinants for the indicators of the use of formal financial services and the use of digital financial services are displayed in table IV. The dependent variable for the use of financial services are formal saving and formal credit while the dependent variable for the use of digital financial services is use of debit card and credit card in past 12 months and bills paid over the internet.

Table IV indicates that age, workforce participation, income and education are significant determinants of formal saving. Age has a non-linear relationship with the formal saving. Higher income, high level of education and workforce participation is positively associated with formal saving. The probability of using formal credit increases with workforce participation by 2.44 per cent and decreases with individual being a woman by 2.18 per cent. 


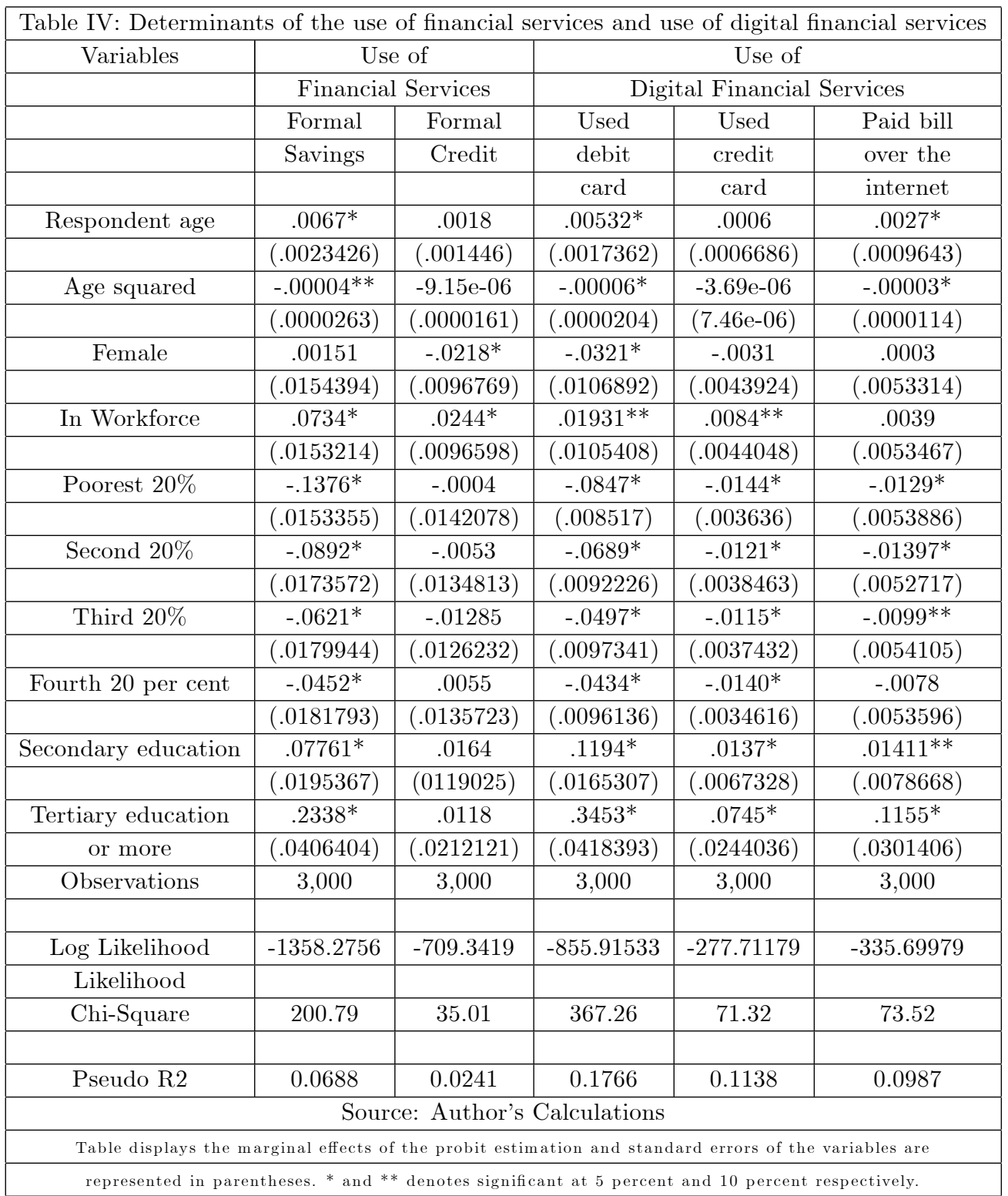

The results for formal credit can be compared with other studies to identify the differences. In India, income and education has no significant association with the use of formal credit from financial institutions. This is in contrast with the findings by Fungáčová \& Weill (2014) and Zins \& Weill (2016) in China and Africa respectively who found that age is non-linearly associated and higher income as well as education is positively associated with the use of formal credit.

With respect to the use of digital financial services, higher education and high income significantly increases the probability of using all the digital financial services. Age is found to have a non-linear relationship with the use of debit card and paying bills over the internet. Workforce participation is a significant positive determinant for the use of debit card and credit card. Being a woman, the probability of using debit card significantly reduces by 3.21 per cent. The results are somewhat similar to the findings by Königsheim et al. (2017) who identified that being a male and having a university degree increases the probability of using digital financial services in Germany and age is found to be negatively associated with the use of digital financials services. 
To sum up, being a woman only decreases the probability of using formal credit but have no effect on formal savings, similar to the trend found by Fungáčová \& Weill (2014) in China and in contrast with the trend found by Zins \& Weill (2016) in Africa. This finding is explained by the abysmally low level of women workforce participation in India thus leaving with little money to be saved at any financial institution ${ }^{3}$. The Workforce participation increases the use of financial services as well as digital financial services except bills paid over the internet. Higher education level increases the use of both digital financial services and financial services except the use of formal credit. Similarly, higher income is positively associated with higher formal savings, use of debit card and credit card but not with formal credit. Likewise, only the lowest income group is negatively associated with the bills paid over the internet.

5.3. Determinants of mobile banking and traditional banking. The determinants of the mobile banking and traditional banking are evaluated for more better understanding of the difference in determinants of financial inclusion and digital financial inclusion. The comparison of the determinants will help in knowing what individual characteristics drive the use of mobile banking in India. The table V displays the results.

\begin{tabular}{|c|c|c|}
\hline \multicolumn{3}{|c|}{ Table V: Determinants of Traditional banking and Money banking } \\
\hline \multirow[t]{2}{*}{ Variables } & Account at a Financial & Mobile Money \\
\hline & Institution & Account \\
\hline \multirow[t]{2}{*}{ Respondent age } & $.0159^{*}$ & $.0014^{*}$ \\
\hline & $(.0022638)$ & $(.0006555)$ \\
\hline \multirow[t]{2}{*}{ Age squared } & $-.00015^{*}$ & $-.00002^{*}$ \\
\hline & $(.0000257)$ & $(8.01 \mathrm{e}-06)$ \\
\hline \multirow[t]{2}{*}{ Female } & -.0198 & $-.0077^{*}$ \\
\hline & $(.0158814)$ & $(.0036855)$ \\
\hline \multirow[t]{2}{*}{ In Workforce } & $.0642^{*}$ & -.0014 \\
\hline & $(.0163838)$ & $(.0035116)$ \\
\hline \multirow[t]{2}{*}{ Poorest 20 per cent } & -.0318 & $-.0109 *$ \\
\hline & $(.0254193)$ & $(.0028566)$ \\
\hline \multirow[t]{2}{*}{ Second 20 per cent } & -.01499 & $-.0111^{*}$ \\
\hline & $(.0242895)$ & $(.0029348)$ \\
\hline \multirow[t]{2}{*}{ Third 20 per cent } & -.0059 & $-.0098^{*}$ \\
\hline & $(.0239231)$ & $(.0028302)$ \\
\hline \multirow[t]{2}{*}{ Fourth 20 per cent } & $-.0472^{* *}$ & $-.0106^{*}$ \\
\hline & $(.0251747)$ & $(.0026949)$ \\
\hline \multirow[t]{2}{*}{ Secondary education } & $.1099^{*}$ & $.0101^{* *}$ \\
\hline & $(.0154057)$ & $(.0054681)$ \\
\hline \multirow{2}{*}{ Tertiary education or more } & $.1873^{*}$ & $.1163^{*}$ \\
\hline & $(.0123853)$ & $(.0299579)$ \\
\hline Observations & 3,000 & 3,000 \\
\hline Log Likelihood & -1436.4049 & -243.78341 \\
\hline Likelihood Chi-Square Value & 186.92 & 139.17 \\
\hline \multirow{2}{*}{ Pseudo R2 } & 0.0611 & 0.2221 \\
\hline & e: Author's Calculations & \\
\hline \multicolumn{3}{|c|}{ Table displays the marginal effects of the probit estimation and standard errors of the variables are } \\
\hline \multicolumn{3}{|c|}{ represented in parentheses. ${ }^{*}$ and ${ }^{*}$ denotes significant at 5 percent and 10 percent respectively. } \\
\hline
\end{tabular}

Traditional banking and Mobile Banking are observed to be non-linearly associated with age and positively associated with education. Traditional banking is positively associated with

\footnotetext{
${ }^{3}$ As per the World Bank data, female workforce participation in India was 20.317 per cent in 2019.
} 
workforce participation. The probability of using mobile banking increases with high income and decreases with an individual being a woman by .77 per cent.

There exists a difference in determinants of traditional banking and mobile banking in India which is in contrast with the results of Zins \& Weill (2016) who concluded the traditional banking and mobile banking to be substitutes in Africa as they had the same determinants. However, in India, being a woman significantly reduces probability of using mobile banking but not traditional banking. This may be attributed to the financial inclusion efforts of the Indian government such as Pradhan Mantri Jan Dhan Yojana (PMJDY) and no-frill accounts which have enabled expansion in mainly traditional banking. Then, higher income is associated with higher probability of just mobile banking and not traditional banking. Workforce participation increases the probability of using traditional banking but do not have significant impact on mobile banking. Thus, mobile banking and traditional banking cannot be treated as substitutes in India.

\section{Conclusion and Policy Implications}

There has been a paradigm shift from financial inclusion to digital financial inclusion in India after 2014 when India introduced the Digital India initiative. Although the access to financial services and digital financial services has improved, it has still not transformed into their frequent use. This necessitated the analysis in the present paper which compares the determinants of financial inclusion and digital financial inclusion by focusing on their determinants for their two main dimensions, access and use. The determinants of mobile banking and traditional banking has also been compared.

One of the main findings is that being a poor and woman significantly reduces the access to digital financials services but not financial services. Also, being a woman significantly reduces probability of using mobile banking but do not affect traditional banking. This is explained by the fact that government has made significant efforts in enhancing the access to financial services such as PMJDY, simplification of Know Your Customer (KYC) requirements by introducing Aadhar card which significantly reduces the cost of opening a bank account. This has improved women's access to financial services but they still lag behind with respect to access to digital financial services. Many a times, women are not involved in the financial management activities of a household which restricts them from accessing digital financial services. Few women, in comparison to men, own laptop or mobile phone which is another reason explaining the low access of digital financial services among women ${ }^{4}$. This emphasises the importance of improving the access to digital financial services as well. Although the government has issued rupay cards to PMJDY account holders, such efforts need to be accompanied by awareness campaigns about various digital financial services available and the benefits associated with them among people, particularly for the poor and women.

High income is found to be positively associated with use of financial services, access to digital financial services, use of digital financial services but not with access to financial services. In similar terms, higher income is associated with higher probability of just mobile banking and not traditional banking. It is also observed that workforce participation has a positive relationship with access and use of both financial services and digital financial services except for bills payments over the internet. Hence, it can be concluded that poverty mainly reduces the likelihood to access and use digital financial services. The reason for this is that poor people have hand-to-mouth income which only covers their daily necessities. Poor people do not enjoy a consistent source of income which also restricts the use of such services. This, in addition to the charges imposed on digital transactions, makes it difficult for the impoverished to use these services. This highlights the need of providing them with stable employment opportunities which can provide a smooth flow of income, thus providing them with the motivation to use

\footnotetext{
${ }^{4}$ According to The Mobile Gender Gap Report 2019 by GSMA, women in low and middle-income countries are 10 per cent less likely than man to own mobile phones and 23 per cent less likely to use mobile internet.
} 
financial services as well as digital financial services. Poor people should also be exempted from the additional charges imposed on the financial transactions and digital transactions at least for some initial periods of the use. Then, education is found to be positively associated with access and use of both financial services as well as digital financial services with formal credit being the only exception. Therefore, increasing the awareness about the various financial services and digital financial services available and various benefits associated with it can help in furthering the financial inclusion and digital financial inclusion.

Thus, the determinants of financial inclusion and digital financial inclusion differs to some extent. While most of the determinants are common for both financial inclusion and digital financial inclusion, women and poor people suffer more from digital financial exclusion than financial exclusion. The results are of particular importance for the policy makers as specialised policies for enhancing the access and use of financial services and digital financial services can be formulated by targeting specific sections of the society.

6.1. Scope for Future Research. The present paper has certain limitations which can provide the scope of future research. There is a need to focus on the determinants of a broader range of financial services such as insurance, remittances and others to get a more robust analysis. The same analysis should be performed using primary data in order to get a more enhanced grass-root level result. Further, the reasons behind the digital financial exclusion of women and poor also needs be explored using a micro-level study.

\section{REFERENCES}

[1] Ahamed, M. Mostak, and Sushanta K. Mallick. 2019. "Is Financial Inclusion Good for Bank Stability? International Evidence." Journal of Economic Behavior and Organization 157 (January): 403-27. https://doi.org/10.1016/j.jebo.2017.07.027.

[2] Allen, Franklin, Asli Demirguc-Kunt, Leora Klapper, and Maria Soledad Martinez Peria. 2016. "The Foundations of Financial Inclusion: Understanding Ownership and Use of Formal Accounts." Journal of Financial Intermediation 27 (2016): 1-30. https://doi.org/10.1016/j.jfi.2015.12.003.

[3] Banna, Hasanul, and Rabiul Alam. 2021. "Is Digital Financial Inclusion Good for Bank Stability and Sustainable Economic Development? Evidence From Emerging Asia." Working Paper No. 1242, Asian Development Bank Institute.

[4] Demirguc-Kunt, Asli, Leora Klapper, Dorothe Singer, and Peter Van Oudheusden. 2015. "The Global Findex Database: Measuring Financial Inclusion around the World." World Bank.

[5] Evans, O. 2018. "Connecting the Poor: The Internet, Mobile Phones and Financial Inclusion in Africa." Digital Policy, Regulation and Governance 20 (6). https://doi.org/10.1108/DPRG-04-2018-0018.

[6] Fernandes, Carla, Maria Rosa Borges, and Jorge Caiado. 2021. "The Contribution of Digital Financial Services to Financial Inclusion in Mozambique: An ARDL Model Approach." Applied Economics 53 (3): 400-409. https://doi.org/10.1080/00036846.2020.1808177.

[7] Fungáčová, Zuzana, and Laurent Weill. 2014. "Understanding Financial Inclusion in China." BOFIT, no. 8: $3-21$.

[8] Geng, Zhechen, and Guosheng He. 2021. "Digital Financial Inclusion and Sustainable Employment: Evidence from Countries along the Belt and Road." Borsa Istanbul Review. https://doi.org/10.1016/j.bir.2021.04.004.

[9] Khera, Purva, Stephanie Ng, Sumiko Ogawa, and Ratna Sahay. 2021a. "Is Digital Financial Inclusion Unlocking Growth?" Working Paper No. 21/167, International Monetary Fund (IMF) Publications.

[10] Khera, Purva, Stephanie Ng, Sumiko Ogawa, and Ratna Sahay. 2021b. "Measuring Digital Financial Inclusion in Emerging Market and Developing Economies: A New Index." Working Paper No. 21/90, International Monetary Fund (IMF) Publications.

[11] Klapper, Leora, Mayada El-zoghbi, and Jake Hess. 2016. "Achieving the Sustainable Development Goals: The Role of Financial Inclusion." CGAP.

[12] Königsheim, Christian, Moritz Lukas, and Markus Nöth. 2017. "Financial Knowledge, Risk Preferences, and the Demand for Digital Financial Services." Schmalenbach Business Review 18 (4): 343-75. https://doi.org/10.1007/s41464-017-0040-0.

[13] Layman, Timothy, and Kate Lauer. 2015. "What Is Digital Financial Inclusion and Why Does It Matter?," CGAP, no. March 2015: 1-5. Accessed June 4, 2021. https://librarynews.lmu.edu/2018/03/what-is-digitalpedagogy-and-why-does-it-matter/.

[14] Manyika, James, Susan Lund, Marc Singer, Olivia White, and Chris Berry. 2016. "Digital Finance for All: Powering Inclusive Growth in Emerging Economies." McKinsey Global Institute. 
https://www.mckinsey.com/ /media/McKinsey/Featured Insights/Employment and Growth/How digital finance could boost growth in emerging economies/MGI-Digital-Finance-For-All-Executive-summarySeptember-2016.ashx.

[15] Mohan, R. 2006. "Economic Growth, Financial Deepening and Financial Inclusion." Reserve Bank of India Bulletin2. http://www.rakeshmohan.com/docs/RBIBulletinNov2006-2.pdf.

[16] Ouma, Shem Alfred, Teresa Maureen Odongo, and Maureen Were. 2017. "Mobile Financial Services and Financial Inclusion: Is It a Boon for Savings Mobilization?" Review of Development Finance 7 (1): 29-35. https://doi.org/10.1016/j.rdf.2017.01.001.

[17] Ozili, Peterson K. 2018. "Impact of Digital Finance on Financial Inclusion and Stability." Borsa Istanbul Review 18 (4): 329-40. https://doi.org/10.1016/j.bir.2017.12.003.

[18] Ozili, Peterson K. 2020. "Contesting Digital Finance for the Poor." Digital Policy, Regulation and Governance 22 (2): 135-51. https://doi.org/10.1108/DPRG-12-2019-0104.

[19] Pazarbasioglu, Ceyla, Alfonso Garcia Mora, Mahesh Uttamchandani, Harish Natarajan, Erik Feyen, and Mathew Saal. 2020. "Digital Financial Services." World Bank.

[20] RBI. 2008. "Financial Inclusion 7.1." Reserve Bank of India. https://www.rbi.org.in/scripts/ PublicationsView.aspx?id=10494.

[21] Sahay, Ratna, Ulric Eriksson von Allmen, Amina Lahreche, Purva Khera, Sumiko Ogawa, Majid Bazarbash, and Kim Beaton. 2020. "The Promise of Fintech: Financial Inclusion in the Post COVID-19 Era." International Monetary Fund.

[22] Shen, Yan, Wenxiu Hu, and C. James Hueng. 2018. "The Effects of Financial Literacy, Digital Financial Product Usage and Internet Usage on Financial Inclusion in China." In MATEC Web of Conferences, 228:1-6. https://doi.org/10.1051/matecconf/201822805012.

[23] Suzman, Mark. 2016. "Digital Financial Services: A Powerful Lever to Reduce Poverty and Achieve the SDGs." JSTOR, no. 6: 70-77.

[24] Thorat, Usha. 2007. "Financial Inclusion - the Indian Experience." RBI Monthly Bulletin, no. June: 1-8.

[25] Trinugroho, Irwan, Hunik Sri Runing Sawitri, Muh Juan Suam Toro, Siti Khoiriyah, and Arief Budi Santoso. 2017. "How Ready Are People for Cashless Society?" Jurnal Keuangan Dan Perbankan 21 (1): 105-12. https://doi.org/10.26905/jkdp.v21i1.1231.

[26] Vo, Duc Hong, Nhan Thien Nguyen, and Loan Thi-Hong Van. 2021. "Financial Inclusion and Stability in the Asian Region Using Bank-Level Data." Borsa Istanbul Review 21 (1): 36-43. https://doi.org/10.1016/j.bir.2020.06.003.

[27] Wang, Qian, Jinbao Yang, Yung ho Chiu, and Tai Yu Lin. 2020. "The Impact of Digital Finance on Financial Efficiency." Managerial and Decision Economics 41 (7): 1225-36. https://doi.org/10.1002/mde.3168. 